\title{
Erratum to: Control of renin gene expression
}

\author{
Sean T. Glenn • Craig A. Jones • Kenneth W. Gross • \\ Li Pan
}

Published online: 19 June 2012

(C) Springer-Verlag 2012

Erratum to: Pflugers Arch - Eur J Physiol

DOI 10.1007/s00424-012-1110-2

This article was originally published with an erroneous title.

The correct title is as given here.

The online version of the original article can be found at http:// dx.doi.org/10.1007/s00424-012-1110-2.

S. T. Glenn $(\bowtie) \cdot$ C. A. Jones $\cdot$ K. W. Gross

Department of Molecular and Cellular Biology,

Roswell Park Cancer Institute,

Elm and Carlton Streets,

Buffalo, NY 14263-0001, USA

e-mail: Sean.Glenn@roswellpark.org

L. Pan

Department of Pathology, Brigham and Women's Hospital,

Boston, MA 62115, USA 